ORIGINAL ARTICLE

\title{
Ethics guiding the action of the hospital manager
}

\author{
Amélia Rego*1, Beatriz Araújo ${ }^{2}$ \\ ${ }^{1}$ Universidade Católica Portuguesa - Bioethics Institute, Porto, Portugal \\ ${ }^{2}$ Universidade Católica Portuguesa - Center for Interdisciplinary Research in Health, Institute of Health Sciences, Porto, Portugal
}

Received: December 4, 2018

DOI: $10.5430 /$ jha.v8n2p14
Accepted: February 11, $2019 \quad$ Online Published: February 26, 2019

URL: https://doi.org/10.5430/jha.v8n2p14

\begin{abstract}
Objective: We believe there are ethical issues that emerge in the management of hospital health units, therefore in this article we discuss the interface between the areas of Bioethics and Management. This research aims to contribute to the operationalization of a profile of ethical competencies to manage hospitals with ethical weighing and linkage to values.

Methods: This is an exploratory and descriptive study with 421 hospital managers of 25 hospitals in the northern zone of Portugal, integrated in the National Health Service. To collect data, we used the Questionnaire of Ethicity in Hospital Management and analyzed the contents of the electronic pages of 36 hospitals about the mission, values and vision they advocate.

Results: In addition to the philosophical perspective of each person, health professionals in hospital management respect the complex multidimensionality, recognizing the singularity and the personal, social and cultural individuality. Values and personal ethics can be a guide for action in the field of health. In the results of this study, we present a framework of ethical competencies for the management of the hospital, which aims to optimize management with ethical weighing with the following dimensions: Decision, Primacy of the human person, Responsibility, Integrity, Training and development, Equity and access, Organization and Social Responsibility.

Conclusions: Based on the results of this study, we conclude that there is a need to implement a matrix of ethical competencies that guide health professionals to respect people and their rights - in the management of health care and services, in clinical practice or in scientific investigation. The managers of the hospitals integrate the guidelines in the code of ethics of their professional group and in the mission, values and institutional vision. Overall, they claim to have a framework of ethical competencies, acting with reference to the ethical paradigm of personalism.
\end{abstract}

Key Words: Ethics, Values, Management, Hospital, Competencies

\section{INTRODUCTION}

In the words of Archer ${ }^{[1]}$ bioethics is an interdisciplinary and transdisciplinary knowledge in permanent construction, given that "bioethics is a form of social ethics, which pursues the realization of shared values" (Renaud). ${ }^{[2]}$ In health care, holistically, bioethics deals with management and with responsible and supportive professional care, whether in the field of scientific research or in the context of health care, institutional and health policy. Therefore, "bioethics seeks the substantiation of action by reflecting on the principles

\section{that determine human action [...]" (Neves). ${ }^{[3]}$}

Bioethics has induced the interdisciplinary discussion in health sciences, a discussion that, in addition to considering the importance of the human values of health care users, is concerned with all the assistance activity, so that each professional interacts in a coherent and ethical way, both with patients and the work team. That is, the interests of the society and the particularities of the interests of citizens, especially the most vulnerable, are appropriately contemplated.

\footnotetext{
*Correspondence: Amélia Rego; Email: ameliarego52@gmail.com; Address: Praça Dr. Cândido Costa Pires, nº 2 - $4^{\circ}$ Esquerdo, 4715-402 Braga, Portugal.
} 
According to Massarollo and Fernandes, ${ }^{[4]}$ "ethics should be considered as an essential part of the Organization's policy and essential for its development and growth..."

Health professionals who work in health units' management have a responsibility in the technical and management organization and in the clinical capacity to respond to the needs of the users. Their biggest challenge, in the current macroeconomic context, is to reconcile the rationalization of health care and resource monetization.

Given the interdisciplinary context of health care, Dupuis ${ }^{[5]}$ points out the greatest challenges of an organizational ethic (i) the complexity of interventions and the multiplicity of players; (ii) imputability, with the difficulties of assuming overall responsibility; (iii) communication and access to relevant information; and (iv) recognition. In this context, each player, whether professional, patient or family, must be recognized, identified and confirmed in their position, despite the complexity of interventions and the multiplicity of players.

Flores ${ }^{[6]}$ distinguishes the ethics of health institutions in two ways: one is normative and preventive with its structure, protocols, procedures and processes; the other is clinical bioethics, especially contextual and casuistic. Clinical bioethics takes into consideration interpersonal relationships and concrete clinical decisions, which have immediate repercussions on the life and health of the patient.

The health manager needs to be a facilitator so that relationships can develop and are guided by the values and mission of the institution. Accomplishing the objectives is only possible if all employees are aware of and committed to achieving them. In addition to the classic parameters such as the availability of resources or the effectiveness of the results expected and obtained, health management must also consider all indicators related to the management and leadership of teams and services, regional and national health policy, resources and economic options (Dupuis). ${ }^{[5]}$

A model profile or image results from the conceptualization and systematization of the essential characteristics of the personality, coupled with the professional requirements related to the interpersonal relations and technical execution of the activities. Besides being well prepared from a human and technical-scientific point of view, the profile of a professional in the position of hospital manager is based on ethical competence - its functions are demanding due to the great complexity and variety, and they are multifaceted, which makes it difficult to establish a barrier between personal and professional requirements. But the ethical conscience "commits itself to the responsibility of seeing, discerning, deciding and acting with lucidity, persistence and according to right reason" (Domingues). ${ }^{[7]}$ Renaud $^{[8]}$ says that we can never claim the place of a sovereign moral judge in regard to the ethical value of concrete actions, but that does not mean that all people are equivalent, that is, that each person fulfils their ethical being with the same depth.

Transversal competencies, which include the person's value system, management, leadership, flexibility, communication, proactivity, emotional intelligence and tolerance in the face of uncertainty, encompass the application and mobilization of knowledge, skills and attitudes. According to Jardim and Pereira, ${ }^{[9]}$ the development of intra and interpersonal transversal competences, as well as professional competencies, are essential.

Ethical-moral competencies can be used to value oneself and others. People guide the exercise of know-how in their work in terms of the capacity for autonomy in decision-making (Dias). ${ }^{[10]}$ Managers are therefore expected to commit to the organization, to possess communication skills, responsibility and vision, to be able to work as a team and to conduct an ethical action.

Ethical and moral values are the necessary basis for rebuilding interpersonal relationships. They also allow for a more understanding look at healthcare users when decisions need to be ethically compatible with beliefs, while maintaining integrity.

In the wisdom of Habermas, ${ }^{[11]}$ ethical expertise is a knowhow that expresses a "universal human competence" since everyone is capable of moral discernment. In this perspective, Zoboli ${ }^{[12]}$ points out that "ethical competence is the application of discernment and knowledge of ethic's common notions in new cases".

The study developed by Junges et al. ${ }^{[13]}$ points to three fundamental pillars in the construction of ethical competence in the exercise of health care, knowing that this competence is always under construction. Such pillars are personal values, training and practice.

Hospitals, as problem-generating institutions, are also places capable of developing the knowledge and transversal competencies in which ethical competence lies. The contact with professional work and wisdom and with the problems and contexts of action framework allows us to learn to look at the processes of knowledge and action. Moreover, when analyzing practices, the integration of knowledge and cooperation among professionals constitutes a process that leads to values guided by ethical conscience, accepting that ethical and deontological rules delimitate the performance.

Managing the health service must be taken seriously and 
responsibly, since health care finds its legitimacy in compliance with the principle of equity, quality, efficiency, effectiveness and acceptability, which implies effective leadership (Mezomo). ${ }^{[14]}$ The power of judgment is the only tool capable of endowing the health professional with criticism of his own reason. Thus, we agree with Gadamer's ${ }^{[15]}$ perspective, when he points out the need to strike a balance between the ability to do, the willing and the acting responsible.

In hospital management, the guidelines that are included in the code of each professional group are sometimes not sufficient, and a more comprehensive ethical reflection is therefore imperative. Some codes of business ethics differ from codes of professional or deontological ethics, although both seek to serve as guides to the behavior of individuals or institutions through ethical and moral guidelines. Deontological codes have long been considered necessary, while the company code is a more recent need and is intended to demonstrate to employees what the company expects from them, that is, to ensure the ethical environment in the hospital. For managers we highlight, specifically: the Code of Ethics of Entrepreneurs and Managers, defined by the Christian Association of Entrepreneurs and Managers; the American College of Healthcare Executives Code of Ethics; the Code of Professional Ethics of the Administrator/Manager in Brazil; and the Code of Ethics of the Human Resources Administrator by Chiavenato, ${ }^{[16]}$ as well as other initiatives, such as the Director's Code of Ethics and Responsibility of the FPH in France. ${ }^{[17]}$

"The recognition of the limited and insufficient character of deontology in a professional field dedicated to health care is recent and is a decisive achievement of bioethics" (Neves). ${ }^{[3]}$ The code of ethics of a health institution allows its values to become explicit, both for internal and external clients, having as benefits the increase of the ethical level of the institution.

This research aims to create a profile of ethical competencies to manage hospitals with ethical weighing and linkage to values. The design and relevance of this study comes from the fact that database research has revealed a lack of studies related to the ethics of health management at a national and international level. The theme of ethical competence for managing hospital health units is almost absent in the studies found in science databases, which demonstrates the need for more production in this area. This research gap, the scope and objectives of this study make it relevant in the current social, political and health sector context.

\section{MethodS}

This research is part of a $\mathrm{PhD}$ project in Bioethics, within the profile of ethical competencies to manage hospital health units, and is identified methodologically as an exploratory and descriptive study.

\subsection{Sample}

The sample of this study is made up of 421 hospital managers working in Care Units/Services, Management Units/Departments and Boards of Administration of 25 Portuguese hospitals from the National Health Service and hospitals within the Ministry of Health. The elements of the sample come from the Public, Private and Social Sectors of the northern zone of Portugal.

The predominant professional group is nurses $(n=191)$, followed by doctors $(n=105)$, administrators $(n=35)$ and professionals from other groups in coordinating technical areas $(n=90)$ of the hospitals under study. The sample is predominantly female $(61.8 \%)$ and its academic profile focuses primarily on undergraduate degree (76.2\%). The Management Care Units/Service is the area that includes the majority of professionals $(56.1 \%)$. They perform hospital management at Management Units/Departments (16.6\%), in Boards of Administration (5.2\%) and in Coordinating technical areas (22.1\%). The predominant management model in hospitals of respondents' origin is the Public Entity Business (73.9\%), followed by the Public-Private Partnership (14.7\%), the Private Sector $(6.2 \%)$ and the Social Sector (Private Institutions of Social Solidarity), with $5.2 \%$.

At the same time, we analyzed the content related to the mission, values and vision publicized in the electronic pages of thirty six hospitals.

\subsection{Instrument and procedures for data collection and analysis}

In the data collection, we used the Questionnaire of Ethicity in Hospital Management (QEHM) (Rego, Araújo \& Serrão), ${ }^{[18]}$ consisting of six dimensions: "Costs and ethics", "Ethical weighing", "Ethical decision", "Accountability and quality", "Economic and ethical restraint" and "Ways to limit costs".

After authorization of the Board of Directors and the approval of the respective ethics committees of the health institutions, the QEHM was applied through a contact designated by each institution. We also accessed the websites of 36 hospitals in 2014.

The data related to the characterization of the sample were analyzed with descriptive statistics. We carried out content analysis according to Bardin ${ }^{[19]}$ for the qualitative analysis of the information regarding the dimensions of the QEHM and the contents advertised in the hospitals' websites referring to the mission, values and vision. 
Table 1. Ethical competencies for the practice of hospital management

\begin{tabular}{|c|c|}
\hline Dimension & Competencies \\
\hline Decision & $\begin{array}{l}\text { Identifies the problem for ethical decision-making; } \\
\text { Gathers additional information for ethical decision-making, results projection and prevention of difficulties and problems; } \\
\text { Deals with complex dilemmas as a team; } \\
\text { Defines who examines the ethical and moral principles of all involved in the process; } \\
\text { Explores alternative options, predicting the consequences of each one; } \\
\text { Supports decision-making in ethical-professional standards (principles and ethical-humanistic values) and organizational } \\
\text { (access and accessibility, costs, resource limitation, safe appropriations...); } \\
\text { Implements decisions; } \\
\text { Modifies the actions that result from the decision-making; } \\
\text { Evaluates the entire process of ethical decision-making; } \\
\text { Develops argumentative and deliberate skills; } \\
\text { Adopts the code of professional ethics as a charter that guides their life and professional behavior; } \\
\text { Grounds the decision-making; } \\
\text { Uses strategies leading to shared decisions and consensus; } \\
\text { Gathers opinion from the Ethics Committee for Institutional Health; } \\
\text { Acts by weighing opinions; }\end{array}$ \\
\hline $\begin{array}{l}\text { Primacy of the human } \\
\text { person }\end{array}$ & $\begin{array}{l}\text { Acts with respect for people's rights: health care users, professionals and other internal and external clients; } \\
\text { Considers the human person as the foundation, the subject and the conclusion of the whole care institution; } \\
\text { When someone is sick, that person becomes the center and the purpose of all hospital activity; } \\
\text { Provides patients with the fundamental rights of the human person, whether material, social or spiritual; } \\
\text { Ensures strict compliance with the preservation of professional secrecy; } \\
\text { Acts with ethical commitment; } \\
\text { Attracts and maintains qualified personnel; } \\
\text { Balances the number of employees with high quality care; } \\
\text { Provides the hospital with the necessary material resources and equipment to carry out its mission; } \\
\text { Promotes teaching and research; } \\
\text { Provides the hospital with the means necessary for efficient employee performance; } \\
\text { Promotes good interpersonal, inter-service/unit and interinstitutional relations; } \\
\text { Determines management deficiencies in departments and care units/services; } \\
\text { Uses strategies that reflect the mission and values of the institution; } \\
\text { Demonstrates the ability to discern, decide and accomplish; } \\
\text { Demonstrates safety and serenity in the performance of hospital management functions; } \\
\text { Their motto is to serve the mission entrusted to them; } \\
\text { Prevents discriminatory organizational practices; } \\
\text { Manages any conflicts arising from differences in the values of patients, family members and collaborators; } \\
\text { Ensures procedures that safeguard the confidentiality and privacy of patients or others; } \\
\text { Promotes a culture of inclusion that avoids ethnic, religious, gender, sexual orientation or age discrimination; }\end{array}$ \\
\hline Responsability & $\begin{array}{l}\text { Develops an ethical ability in professional management; } \\
\text { Develops critical reflection skills of the ethical problems that emerge in hospitals; } \\
\text { Assumes responsibility as a value; } \\
\text { Promotes good management practices; } \\
\text { Adopts processes and methods that facilitate the organization and optimization of resources; } \\
\text { Promotes responsibility as an integrated value in the practice of all professionals; } \\
\text { Complies with and enforces legal, ethical and moral principles, including those that are part of the code of ethics of their } \\
\text { profession; } \\
\text { Dignifies the work of their employees; } \\
\text { Has moral courage to admit mistakes; } \\
\text { Creates a work environment that promotes an ethical conduct; }\end{array}$ \\
\hline Integrity & $\begin{array}{l}\text { Is faithful to a hierarchy of values; } \\
\text { Incorporates the principles and moral values of their conscience into their conduct; } \\
\text { Demonstrates loyalty and transparency towards hierarchical superiors; } \\
\text { Demonstrates exemption in decision-making; } \\
\text { Demonstrates zero tolerance for any abuse of power against patients or employees; } \\
\text { Acts truthfully in all forms of professional and organizational communication; }\end{array}$ \\
\hline
\end{tabular}


Table 1. (continued.)

\begin{tabular}{|c|c|}
\hline Dimension & Competencies \\
\hline $\begin{array}{l}\text { Training and } \\
\text { development }\end{array}$ & $\begin{array}{l}\text { Values their training in ethics as a management tool; } \\
\text { Develops technical, human and conceptual skills; } \\
\text { Updates their cultural and humanistic education; } \\
\text { Uses the best evidence-based scientific practices; } \\
\text { Stimulates the professional development of their employees; } \\
\text { Demonstrates competencies related to the excellence of being, knowing and doing; } \\
\text { Uses in-service training as an opportunity to analyze values, beliefs and moral convictions; } \\
\text { Propagates the code of institutional ethics; } \\
\text { Creates conditions and monitors compliance with the code of institutional ethics; } \\
\text { Assumes a proactive attitude in the processes of innovation and change; } \\
\text { Creates cultural conditions for the continuous improvement of the institution; } \\
\text { Contributes to maintaining the motivation of the employees; } \\
\text { Promotes an organizational climate conducive to job satisfaction; } \\
\text { Adds value through the development of people, knowledge and intellectual capital; }\end{array}$ \\
\hline Equity and access & $\begin{array}{l}\text { Respects the principle of equity as distributive justice; } \\
\text { Leads an appropriate resource management; } \\
\text { Promotes equity in access to health services for all people; } \\
\text { Ethically allocates resources, especially when they are limited; }\end{array}$ \\
\hline Organization & $\begin{array}{l}\text { Acknowledges the complexity of the hospital organization, assuming the coordination of multidisciplinary activities, } \\
\text { attending to the human person; } \\
\text { Has moral authority in the coordination of peers and those who work under their dependence; } \\
\text { Has the spirit of decision and initiative, discipline and the capacity to achieve constant renewal and improvement of } \\
\text { management indicators; } \\
\text { Manages information systems to ensure complete and coordinated documentation of hospital activity, including research } \\
\text { and advocacy of the hospital, patients and professionals; } \\
\text { Manages information in order to promote the good name of the hospital in front of the public; } \\
\text { Adopts participatory management; } \\
\text { Uses updated and reliable instruments to measure the institution's performance; } \\
\text { Leads to improve management standards and practices; } \\
\text { Creates a safety culture in the organizational environment that minimizes clinical or management errors; } \\
\text { Provides a safe and healthy work environment; }\end{array}$ \\
\hline Social responsability & $\begin{array}{l}\text { Addresses financial sustainability; } \\
\text { Uses strategies to reduce waste; } \\
\text { Minimizes the environmental impact of hospital work processes; } \\
\text { Considers nature as a value; } \\
\text { Invests in environmental preservation; } \\
\text { Promotes environmental education. }\end{array}$ \\
\hline
\end{tabular}

\section{Results}

We will now present the ethical competencies that optimize hospital management, using ethical weighing and linkage to values. Table 1 shows the dimensions and ethical competencies for the practice of hospital management. Its elaboration was supported by: the ethical grounding; our experience; the results of the empirical study, because we are convinced that the quantitative approach, due to its characteristics and value, has potentialities and limitations, but it is also capable of translating the phenomena studied in an appropriate language using instruments that provide reliable measures of ethical action (Rego), ${ }^{[20]}$ and the results of the analysis of the data concerning the dimensions of the QEHM and the information available on the websites of 36 hospitals about the mission, values and vision.
The results of this study highlight a framework of ethical competencies of hospital manager that aim at the optimization of management with ethical weighing and linkage to values. The most significant dimensions are: "Decision", "Primacy of the human person", "Responsibility", "Integrity", "Training and development", "Equity and access", "Organization" and "Social responsibility".

\section{DiscuSSION}

We assert that a person is competent when he or she possesses the qualities or skills that are considered indispensable for the job, in agreement with Fleury and Fleury, ${ }^{[21]}$ who defined competence as "knowing how to act responsibly, which involves mobilizing, integrating and transferring knowledge, resources and skills that add economic value to the organiza- 
tion and social value to the individual".

In this study, we developed a profile of ethical competencies to manage hospitals linked to values and will focus on those skills and competencies that managers are required to have in today's changing world of health.

The competencies of the hospital manager influence the results because they contribute strategically to the quality, adequacy and efficiency of the care provided to the population. In this context, the manager, in addition to being competent from a technical, relational and conceptual point of view, must perform their functions with a high ethical sense, considering that "the foundation of ethics is the human person and therefore you can either defend and promote the human person to achieve the quality of life they are capable of, or there is not enough ethical sensitivity in the professional life and in the health organization" (Grande). ${ }^{[2]}$

In the context of health, as in other sectors, the use of technology, ethics and human rights are increasingly intertwined. However, it is important to find an ethical matrix that helps health professionals to always respect people and their rights, whether in the management of care and health services, in clinical practice or in scientific research.

According to Dupuis, ${ }^{[5]}$ bioethics must become organizational in the sense of developing a vision, a discourse and the ingredients for ethical inspiration and the axiological regulation of care organizations such as hospitals.

The hospital manager runs the risk of being lost in the incessant search to give a complete answer to the institutional problems, getting worn out and neglecting what is essential, losing sight of the ultimate target, which is people in a vulnerable condition. This vulnerability presupposes a management that is linked to values, exercising the great human dignity to act in accordance with the right conscience, open to the truth and sensitive to justice. In this way, they will not be unconsciously persuaded by productivity indicators or by efficiency in resource management, forgetting that their decisions have an impact on the health and well-being of people and in the demand for equitable justice.

We are convinced that managers are not always aware of the ethical implications, especially those related to working conditions that allow for quality, full and humanized care. However, our sample emphasizes through the results that the managers' performance corresponds to the ethical and deontological standards recommended for health professions, particularly those included in the Deontological Codes of doctors and nurses.

Gathering the hospital managers' opinion was a fruitful task, since it provided elements that allowed the fulfillment of the objectives that were previously defined. However, we cannot compare them with other studies because we are not aware of other opinion studies within this area, either nationally and internationally.

\section{Conclusions}

In this study it made sense to demonstrate the relevance of the ethical action of the hospital manager and to contribute to the identification of the axiological basis on which managers should be supported. Simultaneously, we created a profile of ethical competencies to manage hospitals with linkage to values and ethical weighing.

Our understanding is that it is appropriate to motivate health professionals in management roles to reconcile their personal motivations with the greater interest of the organization where they work, along with the development of individual competencies. Thus, with continuous learning and improvement, both in the manager's role and in the pondered and assertive reflection regarding the ethical framework.

We believe that ethical competence helps to develop the capabilities to face the challenges of the hospital context as a truly complex organization.

Health care cannot be managed without a clear ethical framework. But so that each hospital consolidates its practical feasibility, we suggest an in-depth reflection, in order to anticipate the resolution of problems specific to the context. To this end, prior to the crisis situation that calls for a weighted decision, the ethical standards of hospital management must be defined, as well as policies, norms and procedures that demonstrate what to do in case of conflicts and reveal who is responsible for its application. The preparation of these guidelines can be coordinated by the Ethics Assistance Committee, involving all the managers of the institution, from the strategic level to the operational level.

By publishing the results of this study, we hope to contribute to the reflection of the managers regarding ethical competencies and the ethical values underlying the health care delivery, acting in consonance. This change in action will be, for us, the context of the implications of this research for hospital management. If this purpose is achieved, we will consider ourselves to be greatly rewarded by our work.

\section{ACKNOWLEDGements}

We are grateful for the precious contribution of Daniel Serrão (1928-2017).

\section{Conflicts of InTEREST Disclosure}

The authors declare they have no conflicts of interest. 


\section{REFERENCES}

[1] Archer L, Biscaia J, Osswald W (Coord.). Bioética [Bioethics]. Lisboa/São Paulo: Editorial Verbo; 1996.

[2] Renaud M. A bioética e a liberdade política [Bioethics and political freedom]. Cadernos de Bioética [Bioethics Journals]. 2014; 19: 35-45.

[3] Neves MCP. Ética, moral, deontologia e bioética; conceitos que pensam a acção [Ethics, moral, deontology and bioethics; concepts that think the action]. In: Neves MCP, Pacheco S (Coord.). Para uma Ética de Enfermagem. Desafios [For a Nursing Ethics. Challenges]. Coimbra: Gráfica de Coimbra; 2004. p. 145-157.

[4] Massarollo MCKB, Fernandes MFP. In: Kurcgant P. (Coord.). Gerenciamento em Enfermagem [Nursing Management]. 2nd ed., Rio Janeiro: Guanabara Koogan; 2010.

[5] Dupuis M. A bioética e seus desafios de hoje e de amanhã [Bioethics and the challenges of today and tomorrow]. In: Cadernos de Bioética [Bioethics Journals]. 2014; 19: 25-33.

[6] Flores FJR. Gestion Hospitalaria y Justicia Social [Hospital Management and Social Justice]. In: Brito, J.H.S. (Coord.) Ética, Justiça e Cuidados de Saúde [Ethics, Justice and Healthcare]. Braga: Universidade Católica Portuguesa, Faculdade de Filosofia; 2009.

[7] Domingues FB. Personalismo, Perpectivas. [Personalism, Perspectives]. Porto: Dominicanos; 2000.

[8] Renaud I. A Pessoa Humana [The Human Person]. Revista Servir. 1990; 38(4): 159-165.

[9] Jardim J, Pereira A. Competências pessoais e sociais: Guia prático para a mudança positiva [Personal and social skills: A practical guide to positive change]. Porto: Edições Asa; 2006.

[10] Dias MFPB. Construção e Validação de um Inventário de Competências: Contributos para a Definição de um Perfil de Competências do Enfermeiro com o Grau de Licenciado [Construction and Validation of a Competency Inventory: Contributions to the Definition of a Competency Profile for Nurses]. Camarate: Lusociência; 2005.

[11] Habermas J. Signification de la pragmatique universelle [Meaning of universal pragmatics]. In Logique des sciences sociales et autres a essais [Logic of social sciences and other essays]. Paris: PUF; 1976.

[12] Zoboli E. Tomada de decisão em bioética clínica: casuística e deliberação moral [Decision making in clinical bioethics: casuistry and moral deliberation]. Revista Bioética [Bioethics Magazine] [Internet]. 2013; 21(3): 389-396. http://dx.doi.org/10.1590/S1983-8 0422013000300002
[13] Junges JR, Zoboli LCP, Patussi MP, et al. Construção e validação do instrumento "Inventário de problemas éticos na atenção primária em saúde" [Construction and validation of the instrument "Inventory of ethical problems in primary health care"]. In: Revista de Bioética [Bioethics Magazine] [Internet]. 2014; 22(2): 309-317. Available from: http://www.scielo.br/scielo.php?pid=S19 83-80422014000200013\&script=sci_arttext

[14] Mezomo JC. Gestão da qualidade na saúde: Princípios básicos [Quality management in health: The basics]. Brasil: Editora Manole Lda; 2001.

[15] Gadamer HG. O carácter oculto da saúde [The hidden nature of health]. Petropolis: Editora Vozes; 2006.

[16] Chiavenato I. 10 mandamentos da Gestão de Pessoas - Um Código de Ética da Nova Administração de Recursos Humanos [10 Commandments of People Management - A Code of Ethics for the New Human Resources Administration] [Internet]. Available from: http: //www . portaladm.adm.br/Tga/tga4.htm

[17] Fédération Hospitalière de France (FHF). Charte de l'éthique et de la responsabilité des directeurs de la FPH [Director's Code of Ethics and Responsibility of the FPH] [Internet]. 2017. Available from: http://www.anfh.fr/actualites/charte-de-1-ethique -et-de-la-responsabilite-des-directeurs-de-la-fph

[18] Rego A, Araújo B, Serrão D. Validação do Questionário de Eticidade na Gestão Hospitalar [Validation of the Questionnaire of Ethicity in Hospital Management]. Revista de Bioética Latinoamericana [Latin American Bioethics Magazine]. 2014; 13(01): 83-101.

[19] Bardin L. Análise de Conteúdo [Content analysis]. Lisboa: Edições $70 ; 2011$.

[20] Rego A. A Metodologia Quantitativa em Ciências Sociais. O Caso da Investigação em Bioética [The Quantitative Methodology in Social Sciences. The Case of Bioethics Research]. In: Revista Portuguesa de Bioética, Cadernos de Bioética [Bioethics Portuguese Magazine, Bioethics Journals]. 2014; 20: 131-141.

[21] Fleury MTL, Fleury A. Construindo o conceito de competencia [Building the concept of competence]. Revista de Administração Contemporânea 5 [Journal of Contemporary Management]. 2001: 183-196. Available from: http://www.scielo.br/scielo.php ?pid=S1415-65552001000500010\&script=sci_arttext

[22] Grande CMPM. A humanização em questão: O estado da arte [Humanization in question: The state of art]. In: Carvalho A S \& Osswald W. (Coord.). Ensaios de bioética [Bioethics essays]. Lisboa: Universidade Católica Editora; 2008. 